\title{
PENGARUH BIMBINGAN GURU PAMONG TERHADAP PENERAPAN KOMPETENSI GURU KEJURUAN
}

\section{Supervisor Guidance Effect on Practice of Vocational Teacher Competence}

\author{
Essa Annisa Syadiah", Sri Handayani, Mustika Nuramalia Handayani \\ 1,2 Program Studi Pendidikan Teknologi Agroindustri, \\ Fakultas Pendidikan Teknologi dan Kejuruan, Universitas Pendidikan Indonesia \\ E-mail: srihandayani@upi.edu
}

\begin{abstract}
ABSTRAK
Program Pengalaman Lapangan (PPL) merupakan salah satu mata kuliah yang harus ditempuh mahasiswa program sarjana kependidikan. Mahasiswa perlu memahami kompetensi guru kejuruan dalam menjalani perannya sebagai guru praktikan PPL. Penerapan kompetensi guru kejuruan pada praktikan PPL dipengaruhi oleh berbagai faktor. Penelitian ini bertujuan untuk mengetahui pengaruh bimbingan guru pamong pada praktikan PPL terhadap penerapan kompetensi guru kejuruan. Metode penelitian yang digunakan yaitu metode deskriptif dengan pendekatan kuantitatif. Teknik pengambilan sampel menggunakan teknik nonprobability sampling jenis sampling jenuh. Hasil penelitian menunjukkan bahwa bimbingan guru pamong memiliki pengaruh positif terhadap penerapan kompetensi guru kejuruan. Hal ini mengandung implikasi jika semakin baik bimbingan guru pamong maka penerapan kompetensi guru kejuruan juga semakin baik.
\end{abstract}

Kata kunci: bimbingan guru pamong, kompetensi guru kejuruan

\begin{abstract}
The teacher internship program called "Program Pengalaman Lapangan" (PPL) is one of courses that must be taken by educational undergraduate students. Students need to understand the competence of vocational teachers in their roles as PPL apprentice teachers. Implementation of vocational teacher competence in PPL is influenced by various factors. This study aims to determine effect of supervisor guidance on vocational teacher competence practice of PPL apprentice teachers. The research method used was descriptive method with a quantitative approach. The sampling technique uses nonprobability sampling technique of saturated sampling type. The results showed that supervisor guidance had a positive effect on practice of vocational teacher competence. This has implications if the better the supervisor guidance, the better practice of vocational teacher competence.
\end{abstract}

Keyword: supervisor guidance, vocational teacher compentence 


\section{PENDAHULUAN}

Program Pengalaman Lapangan (PPL) merupakan salah satu mata kuliah yang harus ditempuh mahasiswa program sarjana kependidikan. PPL bertujuan memberikan pengalaman belajar kepada mahasiswa dengan menghadirkan situasi nyata bagaimana proses belajar mengajar terjadi di suatu sekolah. Mahasiswa berperan sebagai guru praktikan PPL di sekolah mitra dan dibimbing oleh guru pamong. Mahasiswa perlu memahami kompetensi guru kejuruan dalam menjalani perannya sebagai guru praktikan PPL. Guru yang kompeten akan dapat melaksanakan tugas-tugasnya dengan baik. Penerapan kompetensi guru kejuruan pada praktikan PPL dipengaruhi oleh berbagai faktor. Penelitian ini bertujuan untuk mengetahui pengaruh bimbingan guru pamong kepada praktikan PPL terhadap penerapan kompetensi guru kejuruan.

Kompetensi guru kejuruan meliputi kompetensi pedagogik, kepribadian, sosial dan profesional (Undang-undang Nomor 14 tahun 2005). Kompetensi pedagogik guru kejuruan adalah kemampuan pemahaman terhadap peserta didik, perancangan dan pelaksanaan pembelajaran, evaluasi hasil belajar. Kompetensi kepribadian adalah kemampuan personal yang mencerminkan kepribadian yang stabil menjadi teladan bagi siswa dan berakhlak mulia. Kompetensi sosial adalah kemampuan guru untuk berkomunikasi dan bergaul secara efektif dengan siswa, dan masyarakat sekolah. Kompetensi profesional guru kejuruan adalah penguasaan bidang studi khususnya materi pembelajaran produktif di SMK.

\section{METODE}

Jenis penelitian ini adalah penelitian deskriptif kuantitatif. Populasi yang digunakan pada penelitian ini adalah mahasiswa program studi pendidikan teknologi agroindustri FPTK UPI yang melaksanakan PPL pada semester genap tahun ajaran 2014/2015 di beberapa sekolah praktik yaitu SMKN 1 Kuningan, SMKN 2 Indramayu, SMKN 1 Cidaun Cianjur, SMKN 1 Mundu Cirebon, SMKN 4 Garut dan SMKN 1 Cibadak Sukabumi. Penentuan sampel menggunakan teknik nonprobability sampling jenis sampling jenuh sehingga sampel dalam penelitian ini adalah seluruh mahasiswa program studi pendidikan teknologi agroindustri yang melakukan PPL pada semester genap tahun ajaran 2014/2015 sebanyak 32 orang. Instrumen yang digunakan berupa angket yang telah melalui uji validitas dan reliabilitas. Data yang terkumpul dianalisis menggunakan perhitungan presentase jawaban responden. Perhitungan tersebut bertujuan untuk melihat tinggi rendahnya kriteria jawaban yang diberikan responden. Teknik analisis data yang digunakan adalah analisis korelasional dan uji regresi sederhana untuk melihat pengaruh variabel $\mathrm{X}$ terhadap $\mathrm{Y}$. Dalam penelitian ini terdapat satu variabel bebas, yaitu bimbingan guru pamong $(X)$, serta satu variabel terikat yaitu penerapan kompetensi guru kejuruan $(\mathrm{Y})$.

\section{HASIL DAN PEMBAHASAN}

\section{Bimbingan Guru Pamong}

Bimbingan guru pamong yang dimaksud dalam penelitian ini meliputi 4 aspek yaitu bimbingan rencana proses pembelajaran (RPP), fasilitator bagi praktikan, bimbingan kegiatan mengajar dan bimbingan lingkungan sekolah. Berdasarkan hasil penelitian, 69\% responden menyatakan bahwa guru pamong sering memberikan bimbingan kepada praktikan PPL. Guru pamong adalah guru bidang studi tertentu yang bertugas mendampingi dan membimbing mahasiswa selama melaksanakan kegiatan PPL di sekolah. Guru pamong memiliki peran penting dalam membimbing mahasiswa praktikan selama melaksanakan PPL (Dasmo dan Sumaryati, 2014).

Bimbingan guru pamong pada aspek bimbingan RPP disajikan pada gambar 1. Menurut Sagala (2010) penyusunan rencana pembelajaran yang dibuat guru dapat memperbaiki kualitas pembelajaran. Perencanaan pembelajaran yang dibuat guru dituangkan dalam bentuk Rencana Pelaksanaan Pembelajaran (RPP). 


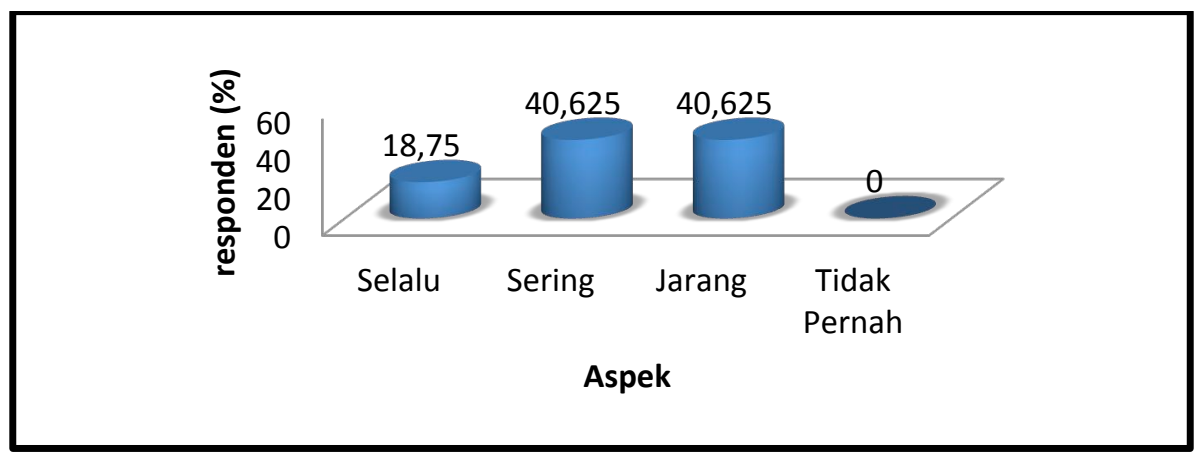

Gambar 1. Bimbingan guru pamong pada aspek RPP

Melalui perencanaan pembelajaran yang lengkap dan sistematis guru akan mampu melaksanakan kegiatan pembelajaran menjadi lebih terarah dan efektif dalam mencapai tujuan pembelajaran yang ditetapkan (Sudjana, 2001). Berdasarkan pendapat tersebut, sebaiknya guru pamong memberikan bimbingan RPP kepada praktikan PPL guna kelancaran dalam pelaksanaan kegiatan pembelajaran kemudian mempermudah dan meningkatkan pembelajaran serta sebagai acuan bagi guru untuk melaksanakan kegiatan belajar yang lebih terarah dan berjalan secara efektif dan efisien.

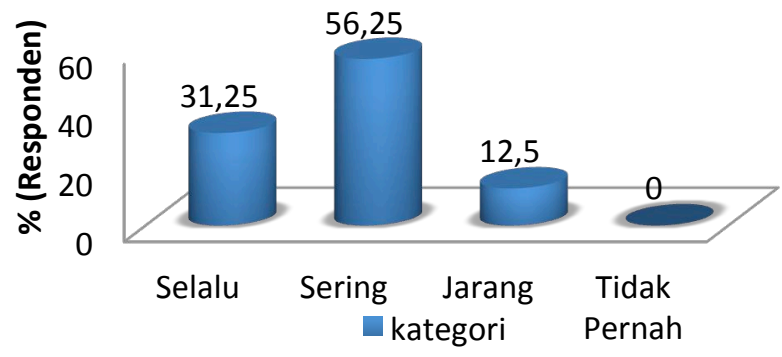

Gambar 2. Bimbingan guru pamong aspek fasilitator praktikan PPL

Bimbingan guru pamong aspek fasilitator praktikan, disajikan pada gambar 2 . Tugas khusus guru pamong diantaranya adalah memfaslitasi dalam mencari data/informasi mengenai struktur sekolah, kurikulum, administrasi sekolah, kesiswaan, perpustakaan dan BP, melatih praktikan dalam penyelesaian administrasi kelas (Dir Akademik UPI, 2014). Hal ini mendukung tugas dari guru pamong yang bertindak sebagai penanggung jawab langsung dalam keseluruhan kegiatan mahasiswa praktek baik akademis maupun non akademis. Sehingga pada pelaksanaan PPL akan terjadi keselarasan antara kinerja praktikan atas bantuan dan bimbingan dari guru pamong. Srijani, N (2007) menyatakan bahwa mahasiswa yang bimbingan guru pamongnya efektif menunjukkan keberhasilan PPL yang lebih tinggi daripada mahasiswa yang bimbingan guru pamongnya kurang efektif.

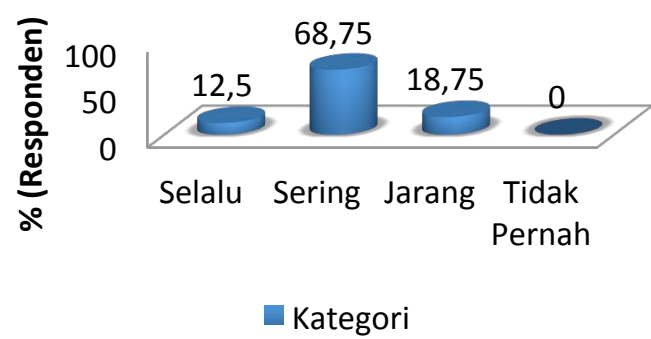

Gambar 3. Bimbingan guru pamong aspek kegiatan mengajar 
Hasil penelitian menunjukkan $68,75 \%$ responden menyatakan bahwa guru pamong sering memberikan bimbingan kegiatan mengajar kepada praktikan seperti yang disajikan pada gambar 3 . Secara umum guru pamong menganggap praktikan harus mampu mempunyai cara mengajar yang baik, karena mengajar adalah hal yang penting untuk tugas sebagai seorang guru. Hal ini mendukung pernyataan Slameto (2010) yang menyatakan bahwa mengajar adalah menanamkan pengetahuan pada seseorang dengan cara paling singkat dan tepat. Secara deskriptif, mengajar diartikan sebagai proses penyampaian informasi atau pengetahuan dari guru kepada siswa. Proses penyampaian itu sering dianggap sebagai mentransfer ilmu. Bimbingan guru pamong pada aspek mengajar sangat dibutuhkan dan erat kaitannya dengan kemampuan praktikan PPL dalam menyampaikan informasi/ transfer ilmu bidang studi yang ditekuninya. Hal ini senada dengan yang diungkap oleh Mukhibad dan Susilowati (2010) guru pamong merupakan guru yang bertugas mendampingi mahasiswa praktikan selama PPL di sekolah latihan dan merupakan guru kelas terkait dengan bidang studi yang ditekuni oleh praktikan. Bimbingan guru pamong yang baik dan efektif dapat membawa pengaruh positif terhadap kemampuan mahasiswa PPL dalam mengajar di kelas (Natalia dkk, 2013).

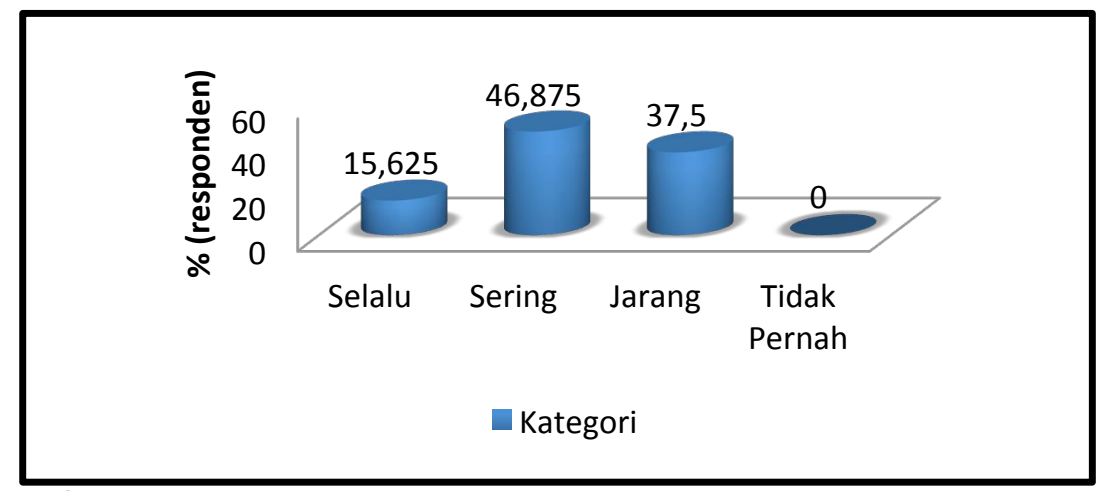

Gambar 4. Bimbingan guru pamong aspek lingkungan sekolah

Bimbingan guru pamong aspek lingkungan sekolah terkait dengan kompetensi sosial yang harus dimiliki guru dimana seorang guru harus memiliki kemampuan dalam berinteraksi dan berkomunikasi dengan siswa dan masyarakat lingkungan sekolah. Hasil penelitian menunjukkan bahwa guru pamong sering memberikan bimbingan lingkungan sekolah kepada praktikan seperti disajikan pada gambar 4. Hal ini sejalan dengan Dir Akademik UPI (2014) dalam buku panduan PPL yang menjelaskan bahwa guru pamong sedianya memperkenalkan praktikan PPL pada lingkungan sekolah. Dalam tahap orientasi PPL, pengenalan lapangan atau lingkungan sekolah merupakan tahap awal sebelum tahap-tahap latihan keterampilan mengajar dilaksanakan. Sebagai warga baru di sekolah, praktikan PPL memerlukan bimbingan dari guru pamong untuk beradaptasi di lingkungan sekolah.

\section{Penerapan Kompetensi Guru Kejuruan}

Hasil penelitian terhadap penerapan kompetensi guru kejuruan oleh praktikan PPL menunjukkan bahwa $62.5 \%$ responden (praktikan PPL) menyatakan sering menerapkan kompetensi guru, seperti disajikan pada gambar 5. Penerapan kompetensi guru kejuruan dalam penelitian ini meliputi aspek kompetensi pedagogik, kompetensi kepribadian, kompetensi profesionalisme dan kompetensi sosial.

Undang-Undang No. 14 tahun 2005 tentang Guru dan Dosen menjelaskan bahwa kompetensi pedagogik merupakan kemampuan seorang guru dalam mengelola proses pembelajaran yang berhubungan dengan peserta didik, meliputi pemahaman wawasan atau landasan kependidikan, pemahaman terhadap peserta didik, pengembangan kurikulum atau silabus, perancangan pembelajaran, pelaksanaan pembelajaran yang mendidik dan dialogis, pemanfaatan teknologi pembelajaran, evaluasi hasil belajar, dan pengembangan peserta didik untuk mengaktualisasikan berbagai potensi yang dimilikinya. 


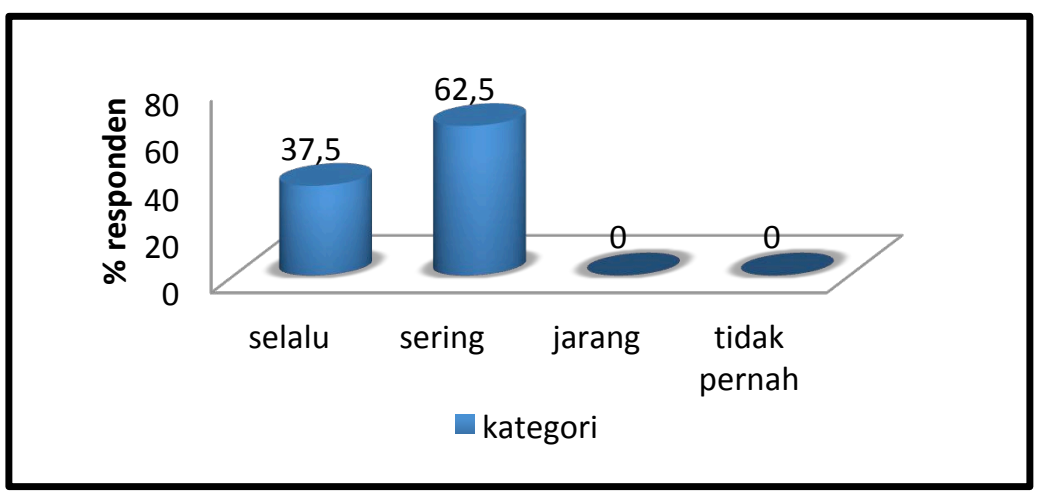

Gambar 5. Penerapan Kompetensi Pedagogik

Hasil penelitian tersebut menunjukkan bahwa sebagian besar praktikan sudah memiliki kemampuan merencanakan pembelajaran, melaksanakan dan melakukan evaluasi terhadap pembelajaran juga memiliki kemampuan dalam memahami perkembangan peserta didik.

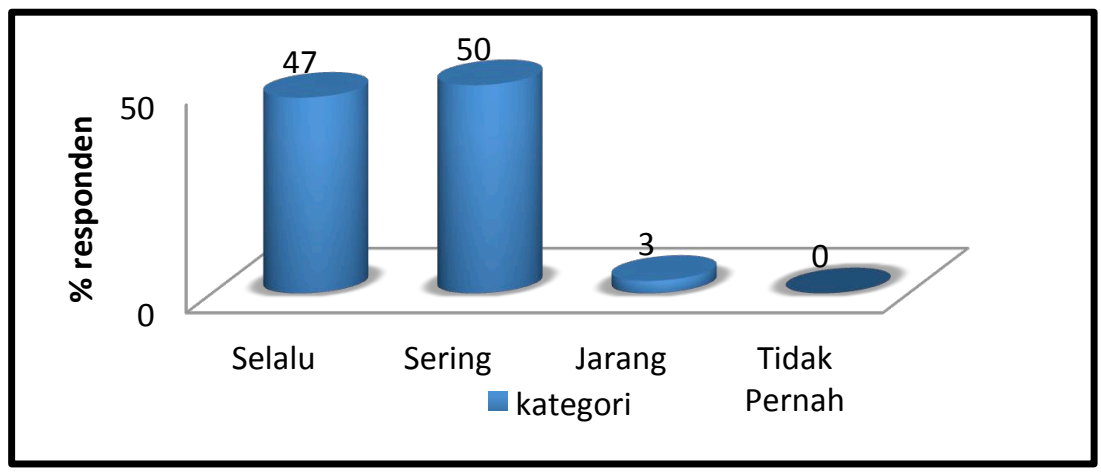

Gambar 6. Penerapan Kompetensi Kepribadian

Hasil penelitian menunjukkan $50 \%$ responden menyatakan sering menerapkan kompetensi guru kejuruan pada aspek kompetensi kepribadian. Pentingnya seorang praktikan memahami dan menerapkan kompetensi kepribadian, bukan hanya karena menjadi seorang guru praktik namun kompetensi kepribadian dapat memberikan bimbingan dan contoh teladan untuk siswa, serta mengembangkan kreativitas dan memotivasi belajar siswa. Aspek kepribadian seorang guru kejuruan pada dasarnya harus sudah tertanam pada jiwa praktikan PPL. Karena kepribadian seorang mahasiswa yang baik akan mudah baginya mempraktikan kompetensi kepribadian seorang guru kejuruan pada saat PPL berlangsung. Keselarasan kemampuan pedagogik harus diimbangi dengan kepribadian guru itu sendiri. Sosok guru seyogyanya dapat membangun kecerdasan intelektual, emosi dan spriritual, sehingga aktualisasi yang ditampilkan dalam kinerjanya adalah sebuah keteladanan dalam belajar.

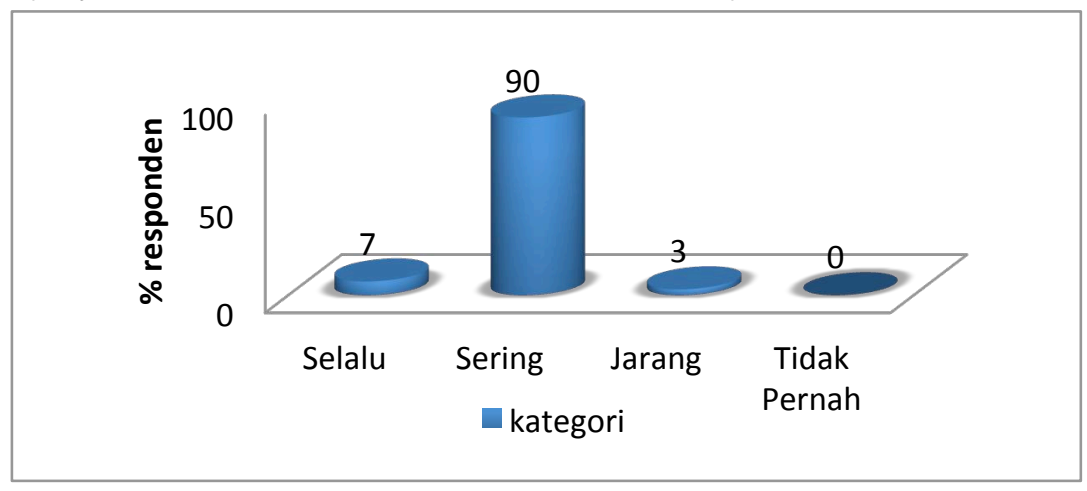

Gambar 7. Penerapan Kompetensi Profesional 
Hasil penelitian menunjukkan $90 \%$ responden menyatakan sering menerapkan aspek profesionalisme guru kejuruan. Kompetensi profesional berkaitan dengan pengetahuan yang luas serta mendalam tentang subjec matter (mata pelajaran) yang diampu dan akan diajarkan, serta penguasaan metodologis dalam arti memiliki pengetahuan konsep teoritik, mampu memilih metode yang tepat, serta mampu menggunakannya dalam proses belajar mengajar. Praktikan PPL berkewajiban mempunyai aspek profesionalisme guru kejuruan. Pada aspek kompetensi profesional, ilmu yang diperoleh selama perkuliahan akan diterapkan pada saat berperan sebagai mahasiswa praktikan atau guru PPL. Disiplin ilmu dan teoritis pelajaran akan berguna ketika mengajar dan praktik di sekolah mitra PPL.

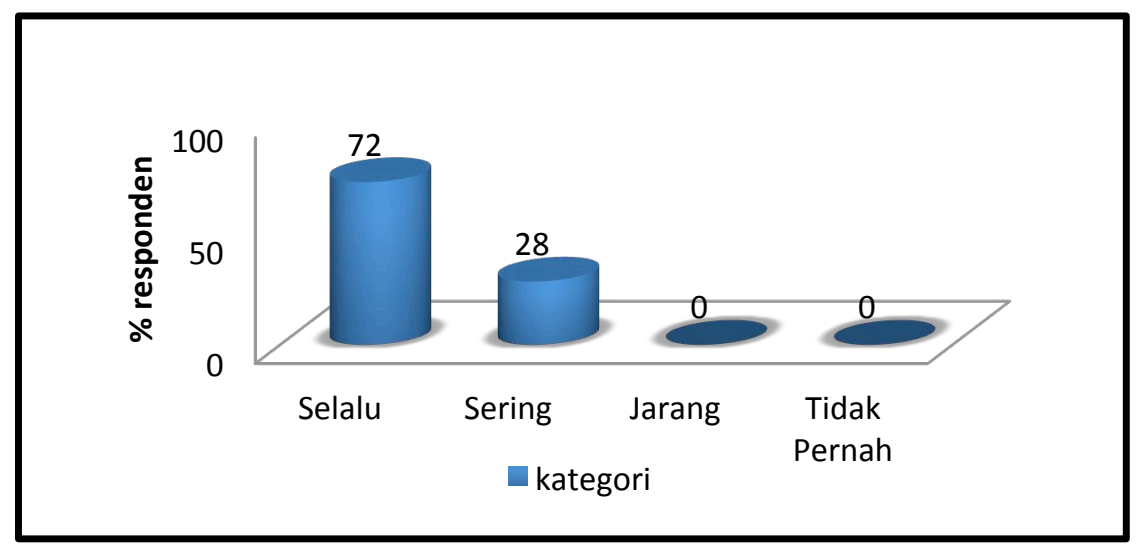

Gambar 8. Penerapan Kompetensi Sosial

Hasil penelitian menunjukkan $72 \%$ responden selalu menerapkan kompetensi guru kejuruan pada aspek kompetensi sosial. Pentingnya sosialisasi yang dilakukan praktikan adalah terciptanya simbiosis mutualisme antara praktikan dengan warga maupun lingkungan sekolah mitra. Hal ini mendukung pernyataan Sumaatmadja (2002) yang menjelaskan bahwa interaksi sosial merupakan bagian yang tidak terpisahkan dengan bimbingan bagi individu, karena tergolong dalam kompetensi aspek apektif yaitu salah satu sikap yang diharapkan pada individu setelah berinteraksi. Interaksi sosial bagi inidividu sangat penting sebagai bekal dan persiapan bagi individu dalam kehidupan bermasyarakat. Sumantri dkk (2007) menjelaskan bahwa Interaksi sosial dapat berguna bagi siswa dalam mengembangkan pemikiran sosial, yang berkenaan dengan pengetahuan dan keyakinan mereka tentang masalah hubungan dan keterampilan sosial. Kompetensi sosial seorang guru kejuruan akan berhubungan dengan interaksi sosial dengan lingkungan tempat mengajar. Interaksi sosial merupakan kunci dari semua kehidupan sosial seorang guru, karena tanpa adanya interaksi sosial maka tidak akan ada kehidupan dalam pergaulan lingkungan mengajar.

\section{Pengaruh bimbingan guru pamong terhadap penerapan kompetensi guru kejuruan}

Korelasi antara bimbingan guru pamong terhadap penerapan kompetensi guru kejuruan dihitung berdasarkan persamaan regresi yang disajikan pada gambar 9. Hasil perhitungan menunjukan bahwa variabel bimbingan guru pamong $\left(X_{1}\right)$ secara linier mempunyai korelasi positif terhadap penerapan kompetensi guru kejuruan $(Y)$ sebesar 0,547 . Hasil tersebut dapat diartikan bahwa jika bimbingan guru pamong meningkat sebesar satu, maka nilai penerapan kompetensi guru kejuruan naik sebesar 0,547. 


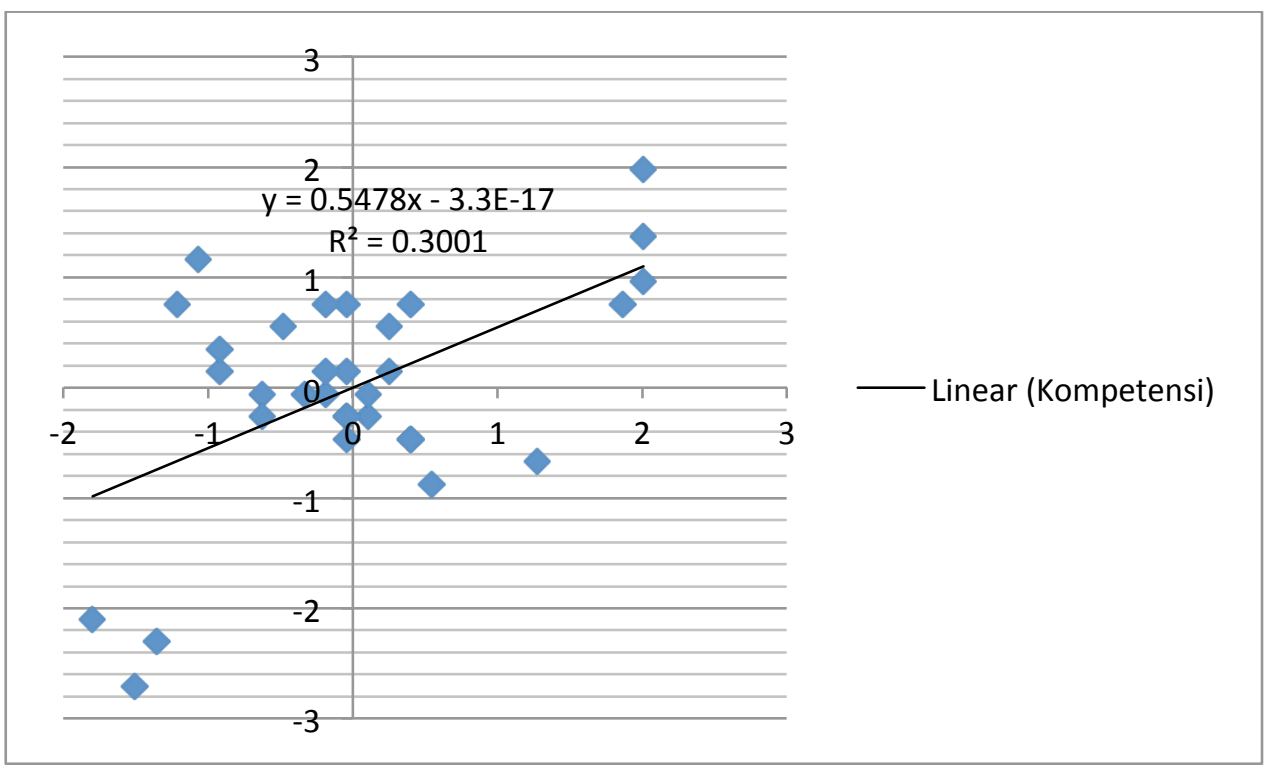

Gambar 9. Regresi $\mathrm{X}_{1}$ (bimbingan guru pamong) terhadap $\mathrm{Y}$ (penerapan kompetensi guru)

Praktikan yang mendapatkan bimbingan dari guru pamong cenderung mempunyai prestasi yang baik dalam melaksanakan PPL. Prestasi yang dimaksud adalah kemampuan menerapkan kompetensi guru kejuruan. Hal ini menunjukan dengan adanya bimbingan yang diberikan guru pamong kepada praktikan, maka akan semakin baik pula penerapan kompetensi guru kejuruan. Hal ini sejalan dengan hasil penelitian Natalia D, dkk (2013) yang mengungkapkan terdapat pengaruh yang positif antara persepsi mahasiswa tentang bimbingan guru pamong terhadap kemampuan mengajar mahasiswa PPL juga Srijani N (2007) mahasiswa yang bimbingan guru pamongnya efektif menunjukkan keberhasilan PPL yang lebih tinggi daripada mahasiswa yang bimbingan guru pamongnya kurang efektif.

Hubungan antara variabel bimbingan guru pamong dan penerapan kompetensi guru kejuruan mempunyai sinergi yang cukup baik. Meskipun berada pada posisi yang cukup kuat, hasil ini didukung oleh hasil persamaan regresi yang menunjukan arah positif. Berdasarkan uji hipotesis menggunakan uji t diketahui bahwa terdapat pengaruh positif antara bimbingan guru pamong terhadap penerapan kompentensi guru kejuruan. Penerapan kompetensi guru kejuruan dipengaruhi oleh bimbingan guru pamong sebesar 30\%. Dengan demikian, berdasar uji korelasi yang cukup kuat dan uji hipotesis yang positif, hipotesis penelitian dapat diterima yaitu bimbingan guru pamong mempunyai pengaruh terhadap kemampuan praktikan dalam menerapkan kompetensi guru kejuruan.

\section{SIMPULAN}

Bimbingan guru pamong mempunyai pengaruh positif terhadap penerapan kompetensi guru kejuruan sehingga semakin baik bimbingan guru pamong maka penerapan kompetensi guru kejuruan juga semakin baik. 


\section{DAFTAR PUSTAKA}

Dasmo, Sumaryati. (2014). Peran Guru Pamong dan Dosen Pembimbing terhadap Keberhasilan Program Pengalaman Lapangan (PPL) Mahasiswa. Jurnal Formatif 4(1): 56-24, 2014.

Dir Akademik UPI. (2014). Panduan Program Pengalaman Lapangan (PPL). Bandung: Universitas Pendidikan Indonesia

Mukhibad, H dan Susilowati, N. (2010). Studi Evaluasi Kompetensi Mengajar Mahasiswa Praktek Pengalaman Lapangan (PPL) Jurusan Akuntansi Universitas Negeri Semarang. Jurnal Lembaran IImu Kependidikan, 39 (2), 112-124

Natalia D, Siswandari, Ngadiman. (2013). Pengaruh Micro Teaching dan Bimbingan Guru Pamong terhadap Kemampuan Mengajar Mahasiswa PPL. FKIP UNS Surakarta. Jupe UNS. Vol. 1/1/ 2013.

Sagala, Syaiful. (2010). Konsep dan Makna Pembelajaran. Bandung: Alfabeta

Slameto. (2010). Belajar dan Faktor-Faktor yang Mempengaruhinya. Jakarta: Rineka Cipta

Srijani, Ninik. (2007). Pengaruh micro teaching dan bimbingan guru pamong terhadap keberhasilan mahasiswa PPL IKIP PGRI Madiun. Jurnal Pendidikan. Vol. 13, No. 01: 52-65. 2007.

Sudjana. (2001). Metode Statistika. Edisi Revisi, Cetakan Keenam, Bandung, Tarsito

Sumaatmadja, N. (2002). Metodologi Pengajaran Ilmu Pengetahuan Sosial. Bandung: PT. Alumni

Sumantri, M dan Syaodih, Nana. (2007). Perkembangan Peserta Didik. Jakarta: Universitas terbuka.

Undang-undang Nomor 14 tahun 2005 tentang guru dan dosen. 